\begin{tabular}{|c|c|c|}
\hline 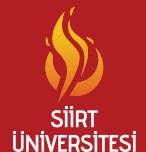 & $\begin{array}{c}\text { Türkiye Tarımsal Araştırmalar Dergisi } \\
\text { dergipark.gov.tr/tutad }\end{array}$ & $\begin{array}{l}\text { Turk J Agric Res } \\
\text { 2018, 5(3): 191-200 } \\
\text { @ TÜTAD } \\
\text { ISSN: 2148-2306 } \\
\text { e-ISSN: 2528-858X }\end{array}$ \\
\hline Bdimin Psugunda & Araştırma Makalesi / Research Article & doi: $10.19159 /$ tutad.368766 \\
\hline
\end{tabular}

\title{
Organik Düzenleyici Uygulamalarının Yapay Yağış Koşullarında Toprakların Bazı Fiziksel Özellikleri ve Toprak Kaybı Arasındaki İlişkiler Üzerine Etkileri*
}

\author{
Nutullah ÖZDEMIRR ${ }^{1}$, Elif ÖZTÜRK ${ }^{2}$, Ömrüm Tebessüm KOP DURMUŞ ${ }^{1 * *}$ \\ ${ }^{1}$ Ondokuz Mayls Üniversitesi, Ziraat Fakültesi, Toprak Bilimi ve Bitki Besleme Bölümü, Samsun, TÜRKIYE \\ ${ }^{2}$ Karadeniz Tarımsal Araştırma Enstitüsü Müdürlüğ̈̈, Tekkeköy-Samsun, TÜRKIYE
}

\begin{tabular}{l}
\hline Geliş Tarihi/Received: 19.12.2017 Kabul Tarihi/Accepted: 02.10.2018 \\
\hline ORCID ID (Yazar sirasma göre / by author order) \\
(Dorcid.org/0000-0003-2554-3485 (D) orcid.org/0000-0003-0363-6648 (Dorcid.org/0000-0003-4761-7705 \\
${ }^{* *}$ Sorumlu Yazar/Corresponding Author: tebessum.kopdurmus@omu.edu.tr
\end{tabular}

Öz: Bu çalışmada ahır gübresi, çeltik kavuzu kompostu ve çöp kompostu uygulamalarına bağlı olarak erozyona karşı duyarlılığın değerlendirilmesinde kullanılan bazı toprak kalite parametreleri ve yüzey akışla oluşan toprak kaybı arasındaki ilişkiler irdelenmiş̧ir. Çalışmada Samsun ili Minöz Havzası'nda yayılım gösteren Entisol ve Inceptisol olarak sınıflandırılan topraklar kullanılmıștır. Calıșmada simülasyon ve toprak kalitesinin belirlenmesi amacıyla her iki toprak için iki farklı deneme kurulmuş, kontrol örneği iki farklı toprak grubu için tek hazırlanmış ve örneklere organik madde içeriğini \% 2, \% 4 ve \% 6 miktarında artıracak şekilde 3 farklı dozda organik düzenleyici uygulanmıștır. Deneme sonucunda topraklara uygulanan organik düzenleyicilerin toprakların bazı fiziksel özelliklerini iyileştirdiğini ve erozyona karşı duyarlılığı düşürerek yüzey akışla meydana gelen toprak kayıplarını azalttığı tespit edilmiștir. Düzenleyicilerin erozyonla oluşan toprak kayıplarını azaltma etkinliği uygulama dozları arasında farklılık göstermekte olup en düşük kayıplar maksimum doz uygulamalarında elde edilmiştir. Çöp kompostu yüzey akış kayıplarını azaltmada; çeltik kavuzu kompostu ve ahır gübresinden daha etkili olmuştur. Erozyona duyarlılık parametrelerinin tahmin gücünün düşük yağış yoğunluklarında daha belirgin olduğu belirlenmiştir.

Anahtar Kelimeler: Organik düzenleyici, fiziksel özellik, toprak kaybı

\section{The Effects of Organic Conditioner Applications on Some Physical Properties of Soils and Their Relations with Soil Loss in Artificial Rain Conditions}

\begin{abstract}
This study investigates the effects of farmyard manure, rice husk and municipal waste compost on soil quality indicators that are used for assessing susceptibility to erosion and soil loss by surface runoff. Two different soil groups, Entisol and Inceptisol, from the Minöz Basin of Samsun province were used. Organic conditioners were applied to the soils per dry weight basis in three different doses $(2,4$ and $6 \%)$ in the simulation and incubation experiments conducted under greenhouse conditions. The results show that the organic conditioners improved the soil physical characteristics and reduced erodibility and soil loss. Effectiveness of the organic conditioners depend on the application dose. The least amount of soil loss was observed at the maximum dose. Municipal waste compost was more effective than rice husk compost and farmyard manure in reducing soil loss by surface runoff. It has been determined that the erosion susceptibility indices are more effective predictors at low rainfall intensities.
\end{abstract}

Keywords: Organic amendments, physical characteristic, soil loss

\footnotetext{
": Bu çalışma; Ondokuz Mayıs Üniversitesi, Fen Bilimleri Enstitüsü “Organik Düzenleyicilerin Toprak Kaybı ve Toprak Kalitesi Üzerindeki Etkilerinin Laboratuar Koşullarında Belirlenmesi” isimli Doktora Tez çalışmasının bir bölümünden üretilmiştir.
} 


\section{Giriş}

Toprağın bulunduğu yerden aşınması, taşınması ve başka bir alanda birikmesi ile tanımlanan erozyon olgusu, toprak ve su kaynaklarının sürdürülebilir şekilde kullanımını kısıtlayan en önemli tehdittir (Lal, 1988). Özellikle kurak ve yarı kurak iklim koşullarındaki eğimli yüzeylerde şekillenmiş aşınıma duyarlı topraklar diğer degredasyon süreçlerine oranla erozyondan daha fazla etkilenmektedirler. Erozyon üst toprak derinliği, toprak organik karbon içeriği, besin elementi durumu, toprak tekstürü, toprak strüktürü, yarayışlı su tutma kapasitesi ve suyun iletimi gibi toprak kalite parametrelerini etkileyerek bitkisel verim düzeyini belirler. Toprakta erozyondan kaynaklanan besin elementi eksikliği ve kimyasal özelliklerde meydana gelen kısıtlamaların öncelikle azot $(\mathrm{N})$, fosfor $(\mathrm{P})$, potasyum $(\mathrm{K})$ ve katyon değişim kapasitesi ile ilişkili olduğu tespit edilmiştir (Lal, 1988).

Toprağın üretkenlik düzeyini negatif yönde etkileyen erozyon sorunu toprak koruma önlemlerinin alınmasını gerektiren büyük bir problem olarak görülmektedir (Özdemir, 2013). Türkiye'nin kurak ve yarı-kurak iklim bölgeleri ile eğimli topoğrafik konumlarda bulunan düşük tarımsal üretime sahip alanlar önceki erozyon süreçleri ile ilişkilidir (Akça ve ark., 2007). Söz konusu üretim alanlarında erozyonla mücadelede en genel yaklaşım; bu topraklarda erozyon riskini azaltarak bitkisel üretimi arttırmak üzere, kültürel ve mekanik önlemlerin alınmasıdır. Organik düzenleyicilerin kullanımı bu doğrultuda önemli etki ya da katkılara sahiptir. Son yıllarda toprak düzenleyici ve organik madde kaynağ1 olarak; ahır gübresi (Haynes ve Naidu, 1998), biyokatı (Albiach ve ark., 2001), kentsel atıklar (Eriksen ve ark., 1999), kompost (Tejada ve Gonzalez, 2003), ürün artıkları (Bandyopadhyay ve ark., 2010), yüksek organik madde içeriğine sahip yan ürünler (Tejada ve Gonzalez, 2004), biyolojik gübreler (Graf ve Frei, 2013; Sönmez ve Y1lmaz, 2016) üzerinde durulmaktadır.

Turgut ve Aksakal (2010), toprağa ilave edilen fiğ samanı ve ahır gübresinin toprağın strüktürel dayanıklılığı ile erozyona dayanıklılığı üzerine etkilerini irdelemişlerdir. Uygulanan düzenleyicilerin toprakların strüktürel dayanıklılığı ve erozyona karşı duyarlılığı üzerine yapmış oldukları etkiler, strüktürel dayanıklılık indeksi, dispersiyon oranı, erozyon oranı, geçirgenlik oranı, agregat stabilitesi ve toprak aşınım faktörü $(\mathrm{K})$ gibi ölçütler yardımıyla değerlendirilmiştir. Çalışma sonucunda, uygulanan organik artıkların çeşit ve uygulama dozlarına bağlı olarak, incelenen toprak özelliklerinde olumlu değişiklikler meydana getirdiği ve toprağın erozyona karşı direncini arttırdığı tespit edilmiştir.

Martinez ve ark. (2003), yarı kurak bir iklim bölgesinde bozulmuş bir toprağa uyguladıkları kompostlaştırılmış kentsel katı atık ve biyokatıların yüzey akışla meydana gelen kayıplar üzerindeki etkisini araştırmışlardır. Araştırıcılar her iki uygulamanın da yüzey akış ve sediment taşınım miktarını önemli ölçüde azalttığını, biyokatı ile muamele edilen parsellerde yüzey akışın daha geç başladığını ve meydana gelen yüzey akış miktarının daha az olduğunu ifade etmişlerdir. Faucette ve ark. (2004) ise tavuk gübresi, çöp kompostu, bahçe atıkları kompostu, yiyecek atıkları kompostu ve üç faklı malç materyali uygulamasının yapay yağış koşulları altında erozyonla meydana gelecek toprak ve besin elementi kayıpları üzerindeki etkilerini inceledikleri çalışmada, uygulamaların toprak kayıplarını azaltmada etkili olduğunu belirlemişlerdir.

Toprağın fonksiyonlarını yerine getirebilme kapasitesi olarak tanımlanan toprak kalitesinin korunmasında, bir başka ifade ile fiziksel, kimyasal ve biyolojik özelliklerdeki bozulmanın kontrol altında tutulmasında, toprağın erozyona karşı direncinin sağlanmasında, su kalitesinin korunmasında, kısaca toprağı bozucu süreçlerin etkisinden uzak tutmada alınabilecek en etkili önlemlerden bir tanesi organik maddenin toprakta devamlı olarak belirli bir düzeyin üzerinde bulunmasını sağlamaktır. $\mathrm{Bu}$ nedenle toprak kalitesinin sürdürülebilirliği açısından organik atıkların düzenleyici olarak değerlendirilmesi oldukça önemlidir (Doran ve Parkin, 1994; Gregorich ve ark., 1994; Lal ve Kimble, 1997). Özellikle yüzey toprağının organik madde kapsamının yeterli düzeyde bulunması; toprağın fiziksel, kimyasal ve biyolojik özelliklerini iyileştireceğinden, toprak kalitesini de arttırmakta ve toprakları erozyona karşı dirençli kılmaktadır (Sojka ve Upchurch, 1999).

$\mathrm{Bu}$ çalışmada, organik düzenleyici uygulamalarının toprağın bazı fiziksel özellikleri ve erozyona karşı duyarlılığı üzerindeki etkileri ile yapay yağış koşulları altında oluşan toplam toprak kaybı arasındaki ilişkiler irdelenmiştir.

\section{Materyal ve Yöntem}

\subsection{Materyal}

Çalışmanın materyalini; Samsun ili sınırları içerisinde bulunan Minöz Havzası'ndan alınan (Entisol ve Inceptisol) yüzey toprak örnekleri (0-20 $\mathrm{cm})$, Ondokuz Mayıs Üniversitesi Ziraat Fakültesi'nden temin edilen ahır gübresi (AG) ve çeltik kavuzu kompostu (ÇKK), İstanbul 
Büyükşehir Belediyesi Kemerburgaz Tesisleri'nden temin edilen çöp kompostu (ÇPK) organik düzenleyicileri oluşturmaktadır.

Çalışmada kullanılan toprak örnekleri; kumlu tın (Entisol) ve killi tın (Inceptisol) bünyeli bir tekstüre, az kireçli ve kireçli toprak yapısına, $\mathrm{pH}$ (1:1) değerleri yönünden çok hafif alkali reaksiyon değerine sahiptirler. Toprakların değişebilir sodyum yüzdesi \% 15'in altında olup, alkalilik sorunu bulunmamaktadır (Tablo 1).

Tablo 1. Çalışma topraklarının bazı fiziksel ve kimyasal özellikleri

\begin{tabular}{|c|c|c|c|c|c|c|c|c|c|c|}
\hline \multicolumn{11}{|c|}{ Fiziksel özellikler } \\
\hline \multirow{2}{*}{ Topraklar } & \multicolumn{4}{|c|}{ Tekstür (\%) } & Renk & \multirow{2}{*}{$\begin{array}{c}\mathrm{HI} \\
\left(\mathrm{cm} \cdot \mathrm{h}^{-1}\right)\end{array}$} & \multirow{2}{*}{$\begin{array}{l}\text { TK } \\
(\%) \\
\end{array}$} & \multirow{2}{*}{$\begin{array}{l}\mathrm{SN} \\
(\%)\end{array}$} & \multirow{2}{*}{\multicolumn{2}{|c|}{$\begin{array}{l}\text { FS } \\
(\%)\end{array}$}} \\
\hline & Kum & Silt & Kil & Sinifi & Kuru-1slak & & & & & \\
\hline Entisol & 67.68 & 22.46 & 9.86 & SL & $2.5 \mathrm{Y} 5 / 3-2.5 \mathrm{Y} 4 / 3$ & 56.57 & 16.1 & 7.4 & 8.7 & \\
\hline Inceptisol & 34.60 & 33.90 & 31.50 & $\mathrm{CL}$ & $2.5 \mathrm{Y} 5 / 3-2.5 \mathrm{Y} 4 / 4$ & 9.56 & 33.6 & 20.1 & 13.5 & \\
\hline \multicolumn{11}{|c|}{ Kimyasal özellikler } \\
\hline & \multirow{2}{*}{$\begin{array}{l}\mathrm{pH} \\
(1: 1)\end{array}$} & \multirow{2}{*}{ 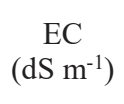 } & \multirow{2}{*}{$\begin{array}{c}\text { Toplam } \\
\text { tuz } \\
(\%)\end{array}$} & \multirow{2}{*}{$\begin{array}{c}\mathrm{CaCO}_{3} \\
(\%)\end{array}$} & \multirow{2}{*}{$\begin{array}{l}\text { OM } \\
(\%)\end{array}$} & \multirow{2}{*}{$\begin{array}{c}\mathrm{KDK} \\
\left(\mathrm{cmol} \mathrm{kg}^{-1}\right)\end{array}$} & \multicolumn{4}{|c|}{$\begin{array}{l}\text { Değişebilir katyonlar } \\
\left(\mathrm{me} 100 \mathrm{~g}^{-1}\right)\end{array}$} \\
\hline & & & & & & & $\mathrm{Na}^{+}$ & $\mathrm{K}^{+}$ & $\mathrm{Ca}^{2+}$ & $\mathrm{Mg}^{2+}$ \\
\hline Entisol & 7.18 & 0.221 & 0.006 & 3.98 & 1.68 & 7.39 & 0.59 & 0.21 & 5.12 & 1.83 \\
\hline Inceptisol & 7.08 & 0.439 & 0.013 & 0.81 & 1.97 & 33.29 & 0.19 & 0.42 & 20.24 & 12.34 \\
\hline
\end{tabular}

HI: Hidrolik iletkenlik, TK: Tarla kapasitesi, SN: Solma noktası, FS: Faydalı su

Araştırmada kullanılan organik düzenleyicilerden çöp kompostu diğerlerine göre daha yüksek $\mathrm{pH}$ değerine ve organik madde içeriğine sahiptir. Azot içeriği çöp kompostu ve ahır gübresinde birbirine yakın olarak belirlenirken, çeltik kavuzu kompostunda bu element daha düşük olarak bulunmuştur. En yüksek fosfor içeriği ahır gübresinde, kalsiyum (Ca) içeriği çöp kompostunda ve demir (Fe) içeriği de çeltik kavuzu kompostunda belirlenmiştir. Diğer element içerikleri ise düzenleyici çeşitlerine bağlı olarak değişkenlik göstermektedir (Tablo 2).

Tablo 2. Kullanılan organik düzenleyicilerin içerikleri

\begin{tabular}{lccc}
\hline Özellik & AG & ÇPK & ÇKK \\
\hline pH & 7.48 & 8.07 & 7.81 \\
$\mathrm{EC}, \mathrm{dS} \mathrm{m}^{-1}$ & 4.29 & 3.10 & 0.51 \\
$\mathrm{OM}, \%$ & 28.32 & 35.71 & 19.82 \\
$\mathrm{OC}, \%$ & 14.16 & 17.86 & 9.91 \\
$\mathrm{~N}, \%$ & 1.74 & 1.55 & 0.88 \\
$\mathrm{C} / \mathrm{N}$ & 8.14 & 11.52 & 11.26 \\
$\mathrm{P}, \%$ & 1.706 & 0.202 & 0.357 \\
$\mathrm{~K}, \%$ & 0.130 & 0.638 & 0.401 \\
$\mathrm{Na}, \%$ & 0.290 & 0.432 & 0.115 \\
$\mathrm{Ca}, \%$ & 2.959 & 9.919 & 0.460 \\
$\mathrm{Mg}, \%$ & 0.588 & 0.345 & 0.364 \\
$\mathrm{Fe}, \%$ & 0.230 & 0.467 & 1.060 \\
$\mathrm{Cu}, \%$ & 0.003 & 0.012 & 0.001 \\
$\mathrm{Zn}, \%$ & 0.025 & 0.025 & 0.008 \\
$\mathrm{Mn}, \%$ & 0.074 & 0.034 & 0.085 \\
\hline $\mathrm{AG} \%$
\end{tabular}

AG: Ahır gübresi, ÇPK: Çöp kompostu, ÇKK: Çeltik kavuzu kompostu, EC: Elektriksel iletkenlik, OM: Organik madde, OC: Organik karbon

\subsection{Yöntem}

Toprakların bazı fiziksel özellikleri ve yüzey akışla oluşacak toprak kayıplarının belirlenmesi için sera koşullarında iki farklı deneme şeklinde yürütülen çalışmada; bozulmuş toprak örnekleri 8 mm'lik elekten, organik düzenleyiciler ise homojen bir karışımın sağlanabilmesi için $4.75 \mathrm{~mm}$ çapındaki bir elekten geçirilmiştir (Karaoğlu ve Çanga, 2002). Topraklara organik düzenleyiciler; kuru ağırlık esasına göre \% 2, \% 4 ve \% 6 oranında uygulanmıştır. Çalışma, iki tekrarlamalı olarak faktöriyel düzende tesadüf parselleri deneme deseni esas alınarak yürütülmüștür. Yüzey akış çalışmalarının gerçekleştirildiği, boyutları $30 \times 29.5 \times 15 \mathrm{~cm}$ (boy-en-derinlik) olan ve tabanında drenaj delikleri bulunan erozyon tavalarının tabanı kaba filtre kağıdı ile örtüldükten (Karaoğlu ve Çanga, 2002) sonra üzerine 10 cm'lik kısmı dolduracak şekilde deniz kumu konulmuştur. Kumun yüzeyi dikkatli bir şekilde düzeltildikten sonra üzerine bir tülbent serilmiş ve tavanın kalan 5 cm'lik kısmına toprak + organik atık karışımları ilave edilmiştir. Benzer şekilde, saksıların tabanına da filtre kağıdı serilerek 10 cm'lik kısmı dolduracak şekilde deniz kumu ilave edilmiş ve üzeri düzeltilerek tülbent serilmiş, $5 \mathrm{~cm}$ 'lik kısma ise toprak + organik atık karıșımları ilave edilmiştir. Deneme saks1 ve tavaları hazırlandıktan sonra karışımlar 12 hafta süre ile inkübasyona tabi tutulmuștur. İnkübasyon döneminde tava ve saksıların nem içerikleri izlenerek elverişli nemin \% 50'si tükenince nem içeriğini tekrar tarla kapasitesine ulaştıracak kadar tekrar su ilavesi yapılmıştır. İnkübasyon döneminin sonunda tava ve saksılardaki topraklar ilgili yöntemler aracılığı ile analize tabi tutulmuşlardır.

Toprakların tekstür analizi, Bouyoucos hidrometre yöntemi ile (Demiralay, 1993); dispersiyon oranı (DO), dispers edilen ve süspansiyonda ölçülen mekanik analiz sonuçlarının kullanımı ile (Ngatunga ve ark., 1984); agregat 
stabilitesi (AS), rslak eleme yöntemine göre (Demiralay, 1993); organik madde (OM), modifiye Walkley-Black yöntemiyle (Kacar, 1994); kireç $\left(\mathrm{CaCO}_{3}\right)$ içeriği, Scheibler kalsimetre yöntemiyle (Kacar, 1994); değişebilir katyonlar [kalsiyum (Ca), magnezyum $(\mathrm{Mg})$, sodyum $(\mathrm{Na})$ ve $\mathrm{K}$ ], amonyum asetat ekstraksiyonu metoduyla (Sağlam, 1997); katyon değişim kapasitesi (KDK), Bower metoduyla (Anonymous, 1954); tarla kapasitesi (TK) ve devamlı solma noktası (SN), basınç tabla aleti kullanılarak (Black, 1965); faydalı su, tarla kapasitesi ve solma noktası arasındaki farktan hesap yoluyla; renk, kuru ve nemli toprakta Munsell renk 1skalası kullanılarak (Dinç ve ark., 1999); hidrolik iletkenlik, sabit seviyeli permeametre yöntemiyle (Özdemir, 1998); pH ve elektriksel iletkenlik (EC) değerleri, saturasyon çamurunda $\mathrm{pH}$ metre (Bayrakl1, 1987) ve EC metreyle (Richards, 1954) ve toplam tuz miktarları ise, EC değerleri ve doygun koşullardaki nem içeriği değerlerinden hesap yoluyla belirlenmiştir.

Organik düzenleyicilerin $\mathrm{pH}$ ve EC değerleri, 1:1 toprak su karışımında (Rowell, 1996) pH ve EC metreyle ölçülerek; organik karbon (OC) ve OM içeriği, kuru yakma metoduna göre (Kacar, 1972); N içeriği, Kjeldahl metoduna göre (Kacar, 1972); P içeriği, phosphomolybdate metoduna göre (Kacar, 1972); değişebilir $\mathrm{Fe}, \mathrm{Cu}, \mathrm{Zn}$ ve $\mathrm{Mn}$ içerikleri, spektrofotometrik yöntemle (Kacar, 1972); C:N oranı, toplam karbon ve azot miktarlarından hesaplanarak belirlenmiștir. Çalıșmada $55 \mathrm{~mm} \mathrm{~h}^{-1}$ ve $70 \mathrm{~mm} \mathrm{~h}^{-1}$ intensiteli yağışla oluşan toprak kayıplarının belirlenmesinde Erpul ve Çanga (2001)'dan modifiye edilen laboratuvar tipi damla oluşturucu düzenek kullanılmıştır (Yakupoğlu, 2010).

\section{Bulgular ve Tartışma}

\subsection{Organik düzenleyicilerin toprak kalite parametreleri üzerine etkileri}

Minöz Havzası'ndan alınan toprak örnekleri kullanılarak yürütülen çalışmada, organik düzenleyici uygulamalarının toprağın bazı fiziksel özellikleri ve yapay yağış koşulları altında toprak kaybı üzerine etkilerinin irdelenmesi amaci ile yüzey akış parselleri ve plastik saksılara paralel iki deneme kurulmuştur. On iki haftalık inkübasyon periyodunun ardindan sonlandirılan deneme saksılarında ve tavalarında belirlenen, toprak kalite parametrelerine ait analiz sonuçları ve yüzey akışla oluşan toprak kayıpları Tablo 3'te; agregat stabilitesi ve dispersiyon oranı değerlerine ilişkin Duncan testi sonuçları ise Tablo 4'te gösterilmiştir. Tablo 4'ün incelenmesinden de görüleceği üzere, kalite parametre değerleri; toprak, uygulanan organik düzenleyici çeşidi ve doz miktarlarına bağlı olarak değişkenlik göstermektedir. Parametre değerleri genel olarak dozların artışına paralel olarak artış göstermiş, en düşük değerler düzenleyici içermeyen kontrol uygulamalarından elde edilmiştir. Toprak kayıplarının daha düşük olarak belirlendiği \% 6 doz uygulamalarında ise analiz edilen kalite parametreleri en yüksek değerlerini almıştır (Tablo 3).

Tablo 3. Entisol ve İnceptisol toprağın bazı kalite parametre değerleri ile $55 \mathrm{~mm} \mathrm{~h}^{-1}-70 \mathrm{~mm} \mathrm{~h}^{-1}$ yoğunluklardaki yağış altında ölçülen toplam toprak kayıpları (ortalamalar)

\begin{tabular}{|c|c|c|c|c|c|c|c|c|c|c|c|c|c|c|c|}
\hline \multirow[t]{2}{*}{ Uygulama } & \multirow{2}{*}{$\begin{array}{l}\mathrm{TK} \\
(\%)\end{array}$} & \multirow{2}{*}{$\begin{array}{l}\mathrm{SN} \\
(\%)\end{array}$} & \multirow{2}{*}{$\begin{array}{l}\text { AS } \\
(\%)\end{array}$} & \multirow{2}{*}{$\begin{array}{l}\mathrm{DO} \\
(\%)\end{array}$} & \multirow[t]{2}{*}{$\mathrm{pH}$} & \multirow{2}{*}{ 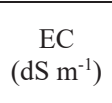 } & \multirow{2}{*}{$\begin{array}{l}\mathrm{OM} \\
(\%)\end{array}$} & \multirow{2}{*}{$\begin{array}{l}\mathrm{N} \\
(\%)\end{array}$} & \multirow{2}{*}{$\begin{array}{c}\mathrm{P} \\
(\mathrm{ppm})\end{array}$} & \multicolumn{4}{|c|}{$\begin{array}{c}\text { Değişebilir katyonlar } \\
\left(\mathrm{me} 100 \mathrm{~g}^{-1}\right)\end{array}$} & \multicolumn{2}{|c|}{$\begin{array}{c}\text { Toprak kayb1 } \\
\left(\mathrm{kg} \mathrm{da}^{-1}\right)\end{array}$} \\
\hline & & & & & & & & & & $\mathrm{Ca}^{++}$ & $\mathrm{Mg}^{++}$ & $\mathrm{Na}^{+}$ & $\mathrm{K}^{+}$ & $55 \mathrm{~mm} \mathrm{~h}^{-}$ & 1011 \\
\hline \multicolumn{16}{|c|}{ Entisol } \\
\hline Kontrol & 18.09 & 8.66 & 65.81 & 27.32 & 6.69 & 0.479 & 2.72 & 0.211 & 13.304 & 15.17 & 2.96 & 0.08 & 0.14 & 11106 & 13524 \\
\hline ÇKK2 & 18.44 & 8.86 & 71.36 & 24.28 & 6.84 & 0.532 & 2.87 & 0.218 & 22.128 & 16.29 & 2.38 & 0.10 & 0.18 & 10320 & 12849 \\
\hline ÇKK4 & 18.89 & 9.25 & 72.88 & 22.72 & 6.96 & 0.654 & 3.01 & 0.227 & 26.541 & 17.38 & 2.75 & 0.11 & 0.20 & 7744 & 12431 \\
\hline ÇKK6 & 19.51 & 9.69 & 75.62 & 20.78 & 7.14 & 0.793 & 3.26 & 0.274 & 35.090 & 18.08 & 3.42 & 0.12 & 0.22 & 6661 & 11140 \\
\hline ÇPK2 & 18.47 & 8.57 & 71.02 & 26.96 & 7.39 & 1.133 & 2.86 & 0.232 & 20.474 & 18.75 & 1.88 & 0.38 & 0.15 & 9597 & 12335 \\
\hline ÇPK4 & 19.02 & 8.74 & 72.16 & 24.77 & 7.48 & 1.490 & 3.11 & 0.266 & 23.783 & 20.46 & 2.67 & 0.63 & 0.17 & 8467 & 11823 \\
\hline ÇPK6 & 19.11 & 8.75 & 74.13 & 23.76 & 7.56 & 2.027 & 3.58 & 0.282 & 31.608 & 21.54 & 3.13 & 0.97 & 0.18 & 6525 & 11545 \\
\hline AG2 & & 9.08 & & 26.93 & 6.97 & 1.1 & & 0.223 & & 16.33 & 4.96 & 0.23 & 0.17 & 10326 & 12889 \\
\hline AG4 & 19.51 & 9.17 & 70.92 & 25.34 & 7.02 & 1.899 & 3.15 & 0.257 & 34.193 & 16.92 & 7.73 & 0.38 & 0.22 & 10106 & 11672 \\
\hline AG6 & 19.35 & 9.70 & 71.37 & 22.28 & 7.08 & 2.500 & 3.49 & 0.279 & 43.294 & 17.63 & 9.71 & 0.54 & 0.27 & 7224 & 11006 \\
\hline \multicolumn{16}{|c|}{ Inceptisol } \\
\hline Kontrol & 22.20 & 10.04 & 44.92 & 28.34 & 7.73 & 0.841 & 2.32 & 0.205 & 14. & 32.68 & 1.13 & 0.08 & 0.2 & 11973 & 15429 \\
\hline ÇKK2 & 22.85 & 10.24 & 46.81 & 26.80 & 7.52 & 0.942 & 2.48 & 0.210 & 23.732 & 31.67 & 2.17 & 0.11 & 0.29 & 10787 & 14871 \\
\hline ÇKK4 & 23.05 & 10.48 & 47.43 & 23.44 & 7.55 & 1.016 & 2.87 & 0.219 & 29.574 & 31.92 & 3.29 & 0.12 & 0.33 & 10079 & 14281 \\
\hline ÇKK6 & 23.20 & 10.74 & 50.19 & 21.85 & 7.64 & 1.043 & 3.11 & 0.237 & 35.366 & 33.08 & 5.88 & 0.13 & 0.34 & 9628 & 12865 \\
\hline ÇPK2 & 22.52 & 9.97 & 50.88 & 27.80 & 7.51 & 1.287 & 2.64 & 0.240 & 22.404 & 30.04 & 3.25 & 0.43 & 0.24 & 9349 & 13914 \\
\hline ÇPK4 & 23.60 & 10.03 & 56.62 & 25.24 & 7.59 & 1.984 & 3.03 & 0.262 & 33.159 & 30.83 & 3.79 & 0.67 & 0.27 & 8168 & 13183 \\
\hline ÇPK6 & 23.41 & 10.17 & 57.93 & 22.54 & 7.60 & 2.181 & 3.39 & 0.365 & 35.641 & 31.67 & 4.58 & 1.09 & 0.35 & 7301 & 12758 \\
\hline AG2 & 22.82 & 10.41 & 47.81 & 27.87 & 7.38 & 1.692 & 2.74 & 0.245 & 26.265 & 29.79 & 6.83 & 0.33 & 0.30 & 10749 & 14748 \\
\hline AG4 & 22.71 & 10.51 & 49.70 & 26.79 & 7.46 & 2.261 & 2.99 & 0.262 & 40.054 & 30.38 & 7.96 & 0.43 & 0.37 & 9070 & 14228 \\
\hline AG6 & 23.30 & 11.01 & 54.59 & 25.33 & 7.56 & 2.867 & 3.35 & 0.339 & 48.758 & 31.75 & 9.29 & 0.65 & 0.51 & 8520 & 13156 \\
\hline
\end{tabular}


Tablo 4. Agregat stabilitesi (AS) ve dispersiyon oranı (DO) değerlerine ilişkin Duncan testi sonuçları

\begin{tabular}{|c|c|c|c|c|}
\hline \multirow{2}{*}{ Topraklar } & \multirow{2}{*}{ Düzenleyiciler } & \multirow{2}{*}{ Dozlar } & AS & DO \\
\hline & & & Ortalama \pm SS & Ortalama \pm SS \\
\hline \multirow{12}{*}{ Entisol } & \multirow{4}{*}{ ÇKK } & Kontrol & $65.8055 \pm 0.00212 \mathrm{~d}$ & $27.3170 \pm 0.00283 b$ \\
\hline & & 1. Doz & $71.3625 \pm 0.00212 \mathrm{cb}$ & $24.2760 \pm 0.00283 \mathrm{ac}$ \\
\hline & & 2. Doz & $72.8765 \pm 0.00212 \mathrm{bb}$ & $22.7220 \pm 0.00283 \mathrm{cc}$ \\
\hline & & 3. Doz & $75.6135 \pm 0.00212 \mathrm{ab}$ & $20.7800 \pm 0.00283 \mathrm{dc}$ \\
\hline & \multirow{4}{*}{ ÇPK } & Kontrol & $65.8055 \pm 0.00212 \mathrm{~d}$ & $27.3170 \pm 0.00283 b$ \\
\hline & & 1. Doz & $71.0195 \pm 0.00212 \mathrm{ca}$ & $26.9530 \pm 0.00283 \mathrm{ab}$ \\
\hline & & 2. Doz & $72.1735 \pm 0.00212 \mathrm{ba}$ & $24.7660 \pm 0.00283 \mathrm{cb}$ \\
\hline & & 3. Doz & $74.1295 \pm 0.00212 \mathrm{aa}$ & $23.7590 \pm 0.00283 \mathrm{db}$ \\
\hline & \multirow{4}{*}{ AG } & Kontrol & $65.8055 \pm 0.00212 \mathrm{~d}$ & $27.3170 \pm 0.00283 \mathrm{~b}$ \\
\hline & & 1. Doz & $67.5255 \pm 0.00212 \mathrm{cc}$ & $31.9270 \pm 0.00283$ aа \\
\hline & & 2. Doz & $70.9215 \pm 0.00212 \mathrm{bc}$ & $25.3340 \pm 0.00283 \mathrm{ca}$ \\
\hline & & 3. Doz & $71.3635 \pm 0.00212 \mathrm{ac}$ & $22.2730 \pm 0.00283 \mathrm{da}$ \\
\hline \multirow{13}{*}{ Inceptisol } & \multirow{4}{*}{ ÇKK } & Kontrol & $65.8055 \pm 0.00164 \mathrm{~d}$ & $27.3170 \pm 0.00219 \mathrm{~b}$ \\
\hline & & 1. Doz & $69.9692 \pm 1.89906 \mathrm{cb}$ & $27.7187 \pm 3.47265 \mathrm{ac}$ \\
\hline & & 2. Doz & $71.9905 \pm 0.88572 \mathrm{bb}$ & $24.2740 \pm 1.22872 \mathrm{cc}$ \\
\hline & & 3. Doz & $73.7022 \pm 1.92927 \mathrm{ab}$ & $22.2707 \pm 1.33225 \mathrm{dc}$ \\
\hline & \multirow{4}{*}{ ÇPK } & Kontrol & $44.9175 \pm 0.00212 \mathrm{~d}$ & $28.3350 \pm 0.00283 \mathrm{~b}$ \\
\hline & & 1. Doz & $46.8035 \pm 0.00212 \mathrm{ca}$ & $26.7970 \pm 0.00283 \mathrm{ab}$ \\
\hline & & 2. Doz & $47.4285 \pm 0.00212 \mathrm{ba}$ & $23.4370 \pm 0.00283 \mathrm{cb}$ \\
\hline & & 3. Doz & $50.1895 \pm 0.00212$ aa & $21.8510 \pm 0.00283 \mathrm{db}$ \\
\hline & \multirow{5}{*}{ AG } & Kontrol & $44.9175 \pm 0.00212 \mathrm{~d}$ & $28.3350 \pm 0.00283 \mathrm{~b}$ \\
\hline & & 1. Doz & $50.8755 \pm 0.00212 \mathrm{cc}$ & $29.7940 \pm 0.00283 \mathrm{aa}$ \\
\hline & & 2. Doz & $56.6135 \pm 0.00212 \mathrm{bc}$ & $25.2360 \pm 0.00283 \mathrm{ca}$ \\
\hline & & 3. Doz & $57.9235 \pm 0.00212 \mathrm{ac}$ & $22.5320 \pm 0.00283 \mathrm{da}$ \\
\hline & & & $\mathrm{p}<0.001$ & $\mathrm{p}<0.001$ \\
\hline
\end{tabular}

Her iki toprak, uygulamalar sonucunda belirlenen kalite parametre değerleri açısından karşılaştırıldığında, parametrelerin İnseptisol toprakta elde edilen verilerin Entisol toprağa oranla biraz daha yüksek olarak belirlendiği görülmektedir. İki toprak arasındaki en belirgin farklılık ise değişebilir $\mathrm{Ca}^{++}$içeriğinde gözlenmiştir. Entisol toprakta kontrol dâhil olmak üzere tüm uygulamaların ortalama değeri $17.85 \mathrm{me}$ $100 \mathrm{~g}^{-1}$ olarak belirlenirken, aynı değer İnseptisol toprak için ise $31.38 \mathrm{me} 100 \mathrm{~g}^{-1}$ olarak bulunmuştur. Uygulamalar arasında değişebilir $\mathrm{Ca}^{++}$içeriği açısından neredeyse 2 katlık bir fark söz konusudur. Kalite parametrelerinde meydana gelen farkl111klar üzerine Tablo 2'de belirtilen düzenleyicilerin özellikleri de etkili olmuştur. Denemede kullanılan düzenleyicilerin özellikleri incelendiğinde, EC değerinin yüksek olması nedeniyle AG uygulamalarında söz konusu parametre değerinin diğer uygulamalara kıyasla daha yüksek olarak belirlendiği görülmektedir. Yine benzer bir etkinin AG uygulamaları için yarayışlı $\mathrm{P}$ ve değişebilir $\mathrm{Mg}^{+}$ içeriklerinde de etkili olduğu saptanmıştır. $\mathrm{pH}$ ve değişebilir $\mathrm{Na}^{+}$içeriğinin diğer düzenleyicilere oranla ÇPK'da daha yüksek olması sebebiyle ilgili düzenleyici uygulamalarında da söz konusu kalite parametre değerleri nispeten yüksek olarak belirlenmiştir.
Parametre değerlerinde meydana gelen değişimler arasında önemli ilişkiler belirlenmiştir. Toprakların OM içerikleri ile toplam N, yarayışlı $\mathrm{P}$, değişebilir $\mathrm{Mg}$, EC ve AS değerleri arasında \% 1 düzeyinde önemli pozitif korelasyonlar; OM ile DO değerleri arasında ise \% 5 düzeyinde önemli negatif bir ilişki belirlenmiştir. Toprakların $\mathrm{Na}$ ve K içerikleri, yarayışlı $\mathrm{P}$ ve tarla kapasitesi parametreleri arasında da \% 5 düzeyinde önemli pozitif korelasyonlar bulunmuştur. Benzer şekilde diğer kalite parametreleri arasında da $\% 1$ ve $\% 5$ düzeylerinde olmak üzere önemli pozitif ve negatif ilişkiler elde edilmiştir (Tablo 5).

Toprakların kalite durumlarının değerlendirilmesinde yararlanılan parametreler arasındaki farklı düzeylerdeki korelasyonlar pek çok araştırmacı tarafından da benzer şekilde ortaya konulmuştur. Çimrin ve Boysan (2006), Van yöresi toprakları üzerinde yürüttükleri çalışmalarında, toprakların toplam $\mathrm{N}$ içerikleri ile $\mathrm{OM}$, yarayışlı $\mathrm{P}$ ile OM içerikleri arasında benzer korelasyonlar elde etmişlerdir. Kara (2012), çeltik kavuzu kompostunun bitki su tüketimi ve toprak kalitesine etkisini belirlemek amaciyla yürüttüğü çalışmasında, söz konusu toprak özellikleri arasında $\% 1$ ve $\% 5$ düzeyinde önemli pozitif ve negatif korelasyonlar elde etmiştir. Sağlam (2013), 
toprakların 14 farklı fiziksel ve kimyasal kalite parametrelerini kullanarak yürüttüğü çalışmasında, ilgili parametreler arasında $\% 1$ ve
$\% 5$ düzeylerinde önemli pozitif ve negatif korelasyonlar belirlemiş; AS ile OM ve EC arasında ise önemli pozitif korelasyonlar elde etmiştir.

Tablo 5. Uygulamalar sonucunda belirlenen her iki toprak ordosuna ait bazı kalite parametreleri arasındaki ilişkilere ait korelasyon katsayıları

\begin{tabular}{llll}
\hline Parametreler & \multicolumn{1}{c}{$\mathrm{r}$} & Parametreler & $\mathrm{r}$ \\
\hline Toplam N-OM & $0.737^{* *}$ & DO-OM & $-0.671^{* *}$ \\
Yarayışlı P-OM & $0.777^{* *}$ & DO-Toplam N & $-0.416^{* *}$ \\
OM-Değişebilir Mg & $0.594^{* *}$ & DO-Yaray1şlı P & $-0.533^{* *}$ \\
Toplam N-Mg & $0.528^{* *}$ & Değişebilir K-EC & $0.636^{* *}$ \\
Yarayışli P-Toplam N & $0.720^{* *}$ & Değişebilir K-Değ. Mg & $0.566^{* *}$ \\
Değişebilir Ca-pH & $0.877^{* *}$ & Değişebilir Mg-EC & $0.751^{* *}$ \\
Değişebilir Ca-TK & $0.962^{* *}$ & Toplam N-EC & $0.757^{* *}$ \\
Değişebilir Ca-SN & $0.860^{* *}$ & OM-EC & $0.641^{* *}$ \\
AS-OM & $0.566^{* *}$ & Yarayişli P-Mg & $0.799^{* *}$ \\
Yarayişli P-EC & $0.812^{* *}$ & Değişebilir K-EC & $0.636^{* *}$ \\
pH- Değişebilir K & $0.572^{* *}$ & Değişebilir K-Değişebilir Mg & $0.566^{* *}$ \\
Yarayişli P-Değişebilir K & $0.683^{* *}$ & TK-SN & $0.919^{* *}$ \\
Değişebilir Na-Değişebilir K & $0.319^{*}$ & EC-SN & $0.409^{* *}$ \\
EC-TK & $0.390^{* *}$ & Yarayişli P-SN & $0.492^{* *}$ \\
Yarayişli P-TK & $0.337^{*}$ & Değişebilir K-SN & $0.898^{* *}$ \\
Değişebilir K-TK & $0.808^{* *}$ & TK-EC & $0.791^{* *}$ \\
pH-SN & $0.665^{* *}$ & & \\
\hline
\end{tabular}

*: $<<0.05,{ }^{* *}: \mathrm{p}<0.01$ düzeyinde önemli

\subsection{Bazı fiziksel toprak özellikleri ve toprak kaybı arasındaki ilişkiler}

\subsubsection{Agregat stabilitesi}

Toprakların agregat stabilitesi (AS) değerlerine ilişkin analiz sonuçları Tablo 3'te, yüzey akışla oluşan toprak kayıpları ile AS arasındaki ilişkiler ise Şekil 1'de verilmiştir. Tablo 3'te verilen AS değerleri incelendiğinde, İnseptisol toprakta AS değerlerinin Entisol topraklardan daha düşük olarak belirlendiği görülmektedir. Agregat stabilitesi değerleri Entisol toprak uygulamalarında \% 65.81\% 75.62 aralığında değişirken, İnseptisol toprak uygulamalarında ise \% 44.92-\% 57.93 aralığında değerler almıştır. Agregat stabilitesi değeri, toprakların erozyona karşı dirençleri ve tarımsal uygulamaların etkilerinin test edilmesine imkân veren bir parametre olarak değerlendirilmektedir. Oran değeri büyüdükçe erozyona karşı duyarlılık azalmaktadır. Ancak toprakların AS değerlerini esas alarak onları erozyona karşı değerlendirecek bir sınır değer henüz geliştirilememiştir (Özdemir, 2013). Bu değerlendirme esas alındığında Entisol toprağın İnseptisol toprağa oranla erozyona karş1 daha dirençli olduğu, düzenleyici uygulamalarına bağlı olarak dayanıklılığın artığı, etkinin düzenleyici çeşitleri arasında farklılık gösterdiği ve düzenleyicilerin etkinlik sıralamasının Entisol toprakta $\mathrm{C} K \mathrm{~K}>\mathrm{C} P K>\mathrm{AG}$, Inceptisol toprakta ise ÇPK $>A G>C$ KK şeklinde olduğu belirlenmiştir.

Diğer taraftan toprak kayıları ile uygulanan düzenleyici ilişkisi irdelendiğinde, toprak kayıplarının artan düzenleyici dozuna bağlı olarak azaldığı, en düşük toprak kaybının organik düzenleyicilerin maksimum doz uygulamasında meydana geldiği tespit edilmiştir. Toprak kaybının Entisol toprakta İnceptisol toğrağa oranla daha düşük düzeyde gerçekleştiği saptanmıştır. Yine yağış yoğunluğu arttıkça organik düzenleyicilerin toprağı koruyucu etkinliklerinin azaldığı ve yüzey akış kayıplarının arttığı görülmüştür (Tablo 3).

Bir başka ifade ile agregat stabilitesinde meydana gelen değişim ile yüzey akışla meydana gelen kayıplar arasında yakın fakat negatif yönlü bir ilişsinin bulunduğu görülmüştür (Şekil 1). Elde edilen ilişki incelendiğinde ölçümü arazi koşullarında zor ve zaman alıcı olan toprak kayıplarının agregat stabilitesi analiz sonuçlarından yararlanarak tahmin edilebileceğini, erozyona duyarlılık ölçütünün toprak kayıplarını tahminleme gücünün düşük yağış yoğunluklarında (Şekil 1a, 1c) yüksek yağış yoğunluklarına (Şekil 1b, 1d) oranla daha yüksek olduğunu, uygulama işlemlerinin toprak kayıplarının ulaşacağı boyuta etkisinin test edilmesine imkân verdiği anlaşılmaktadır.

Organik düzenleyici uygulamalarının toprak kalite parametreleri üzerindeki olumlu etkileri pek çok araştırmacı tarafindan da ortaya konulmuştur. İç ve Gülser (2008), farklı bünyedeki topraklara organik madde kaynağı olarak tütün atığ 1 uygulamasının toprakların $\mathrm{pH}$ ve hacim ağırlığ değerlerinde önemli düzeyde azalmalara, EC, OM ve hidrolik iletkenlik değerlerinde ise önemli 
düzeyde artışlara sebep olduğunu belirlemişlerdir. Whalen ve ark. (2000), ahır gübresi uygulamasının toprağın değişebilir $\mathrm{Ca}, \mathrm{Mg}, \mathrm{K}$ ve yarayışlı $\mathrm{P}$ içeriklerini arttırdığını, potasyumun ahır gübresi uygulanmamış kontrole göre yaklaşık \% 5 oranında arttığını bildirmişlerdir. Clark ve ark. (1998), topraklara organik düzenleyicilerin uygulanması sonucunda değişebilir $\mathrm{Ca}, \mathrm{Mg}$ ve $\mathrm{K}$ içeriklerinin arttığını ifade etmişlerdir. Karaca (2004), 6 aylık

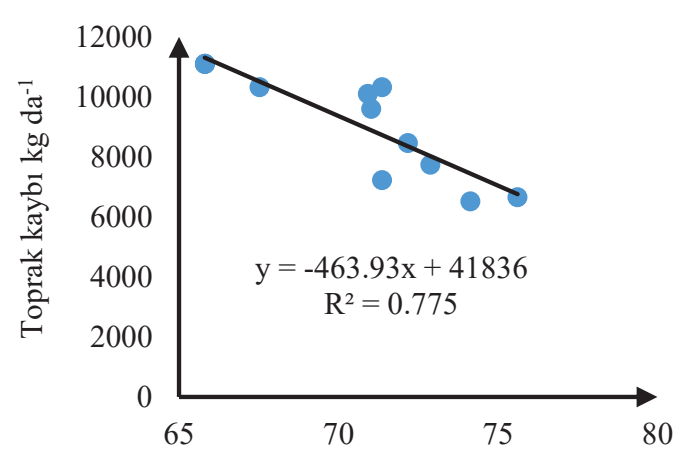

a. Agregat stabilitesi, \%

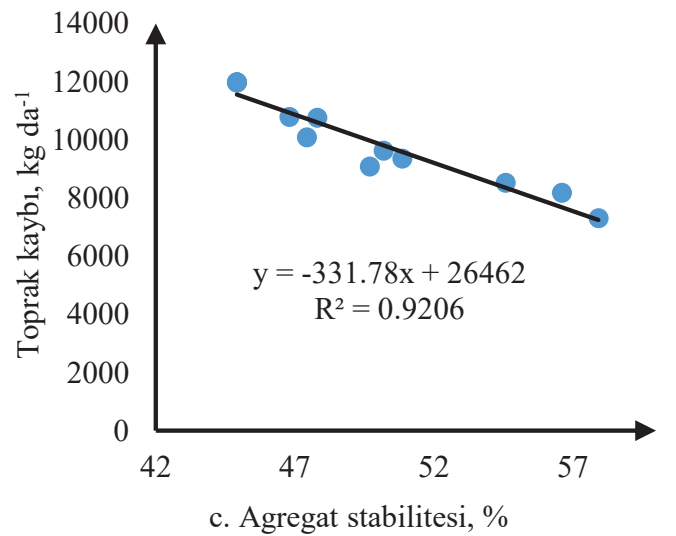

inkübasyon süresince mantar kompostu, üzüm şırası ve tütün atıklarının toprak özellikleri üzerindeki etkilerini incelemiştir. Araştırmacı, mantar kompostu ve üzüm şırası uygulamalarının toprakların $\mathrm{pH}$ değerlerini azalttığını ayrıca tüm uygulamaların toprakların organik madde içeriğinde önemli düzeylerde artışlar meydana getirdiğini belirlemiştir.

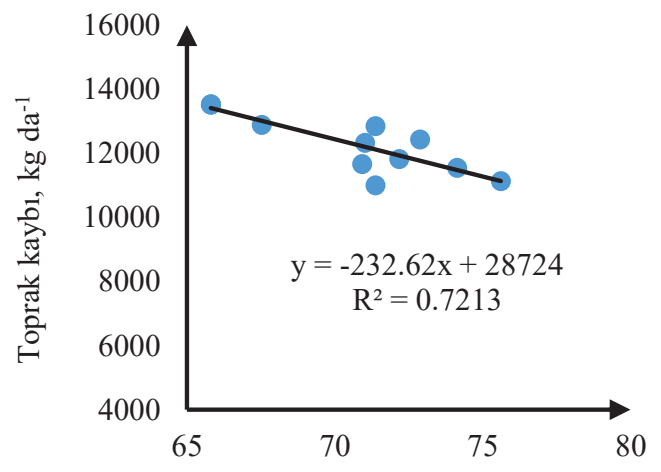

b. Agregat stabilitesi, \%

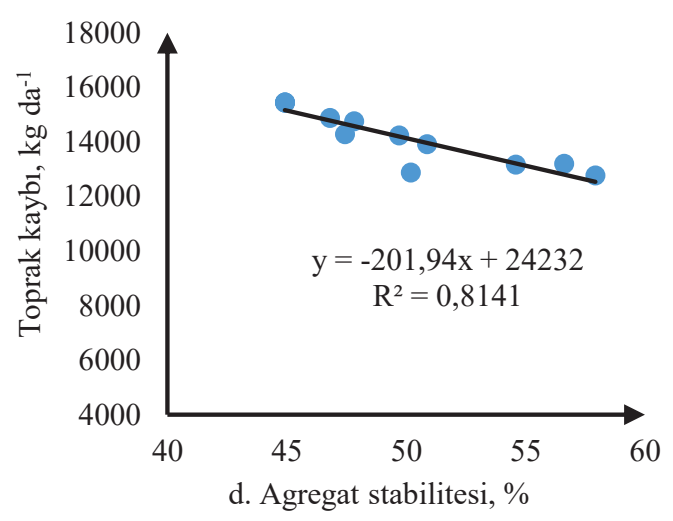

Şekil 1. Entisol (a. $55 \mathrm{~mm} \mathrm{~h}^{-1}$, b. $70 \mathrm{~mm} \mathrm{~h}^{-1}$ ) ve Inceptisol (c. $55 \mathrm{~mm} \mathrm{~h}^{-1}$, d. $70 \mathrm{~mm} \mathrm{~h}^{-1}$ ) toprakta agregat stabilitesi ile toprak kaybı arasındaki ilişkiler

\subsection{Dispersiyon oranı}

Toprakların dispersiyon oranı (DO) değerlerine ilişkin analiz sonuçları Tablo 3'te, yüzey akışla oluşan toprak kayıpları ile DO arasındaki ilişkiler ise Şekil 2'de verilmiştir. Tablo 3'te verilen DO değerleri incelendiğinde Entisol toprakta dispersiyon oranının minimum değeri \% 20.78 ile ÇKK uygulamasının \% 6 dozunda belirlenirken, maksimum değer ise \% 27.32 ile kontrol uygulama dozunda elde edilmiştir. İnseptisol toprakta aynı parametre minimum değerini \% 21.85 ile ÇKK uygulamasının \% 6 dozunda alırken, maksimum parametre değeri ise \% 28.30 ile denet dozundan elde edilmiştir. Dispersiyon oranı parametresi her iki toprak içinde en düşük değerini $\% 6$ doz uygulamasında alırken, en yüksek değerleri denet doz uygulamalarında almışlardır. DO değeri, toprakların erozyona karşı dirençlerinin değerlendirilmesinde kullanılan bir parametre olup oran değeri \% 15'in altında olan topraklar erozyona karşı dayanıklı olarak değerlendirilmektedir (Özdemir, 2013). Bu değerlendirme esas alındığında Entisol toprağın İnseptisol toprağa oranla erozyona karşı daha dirençli olduğu, düzenleyici uygulamalarına bağlı olarak dayanıklılığın arttığ arasında farklılık gösterdiği ve düzenleyicilerin etkinlik sıralamasının her iki toprak içinde ÇPK $<$ ÇPK $<$ AG şeklinde olduğu belirlenmiştir. 

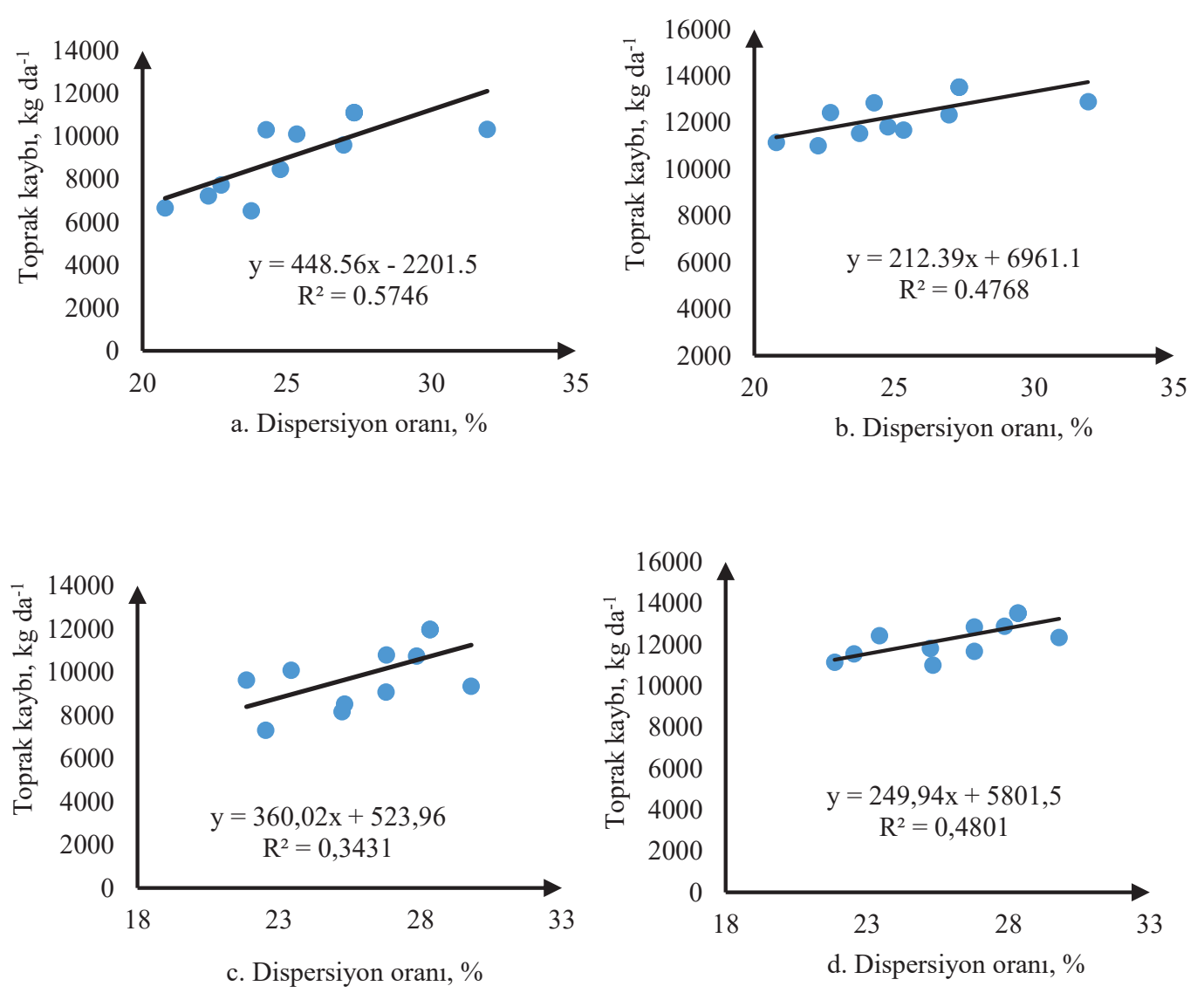

Şekil 2. Entisol (a. $55 \mathrm{~mm} \mathrm{~h}^{-1}$, b. $70 \mathrm{~mm} \mathrm{~h}^{-1}$ ) ve Inceptisol (c. $55 \mathrm{~mm} \mathrm{~h}^{-1}$, d. $70 \mathrm{~mm} \mathrm{~h}^{-1}$ ) toprakta dispersiyon oranı ile toprak kaybı arasındaki ilişkiler

Toprakların kalite durumlarının değerlendirilmesinde yararlanılan parametreler arasındaki farklı düzeylerdeki korelasyonlar pek çok araştırmacı tarafindan da benzer şekilde ortaya konulmuştur. Sağlam (2013), toprakların 14 faklı fiziksel ve kimyasal kalite parametrelerini kullanarak yürüttüğü çalışmasında, ilgili parametreler arasinda $\% 1$ ve $\% 5$ düzeylerinde önemli pozitif ve negatif korelasyonlar belirlemiştir. Araştırmacı AS ile OM ve EC arasında önemli pozitif korelasyonlar elde etmiştir. Candemir (1998), Çarşamba Ovası yüzey topraklarının bazı fiziksel ve kimyasal özellikleri ile strüktürel dayanıklılıkları ve erozyona duyarlılık ölçütleri arasındaki ilişkileri araştırmıştır. Araştırmanın sonucunda, toprakların kil içeriği, katyon değişim kapasitesi, organik madde içeriği, tarla kapasitesi, solma noktası, likit ve plastik limit değerleri arasında önemli korelasyonlar elde edilmiştir.

Diğer taraftan dispersiyon oranı parametresi ile yüzey akışla meydana gelen toprak kayıpları arasındaki ilişkiler irdelendiğinde bu iki parametre arasında pozitif bir ilişkinin bulunduğu görülmüştür (Şekil 2). Toprak kayıplarının artan yağış yoğunluğuna bağlı olarak arttığı ve toprak kaybı ile dispersiyon oranı arasındaki ilişkinin zayıfladığı, bir başka ifade ile dispersiyon oranı parmetresinin yüzey akışla oluşan toprak kayıplarını tahminleme oranının düştüğü anlaşılmaktadır (Şekil 2a, 2b, 2c, 2d). Bu veriler 1şığında arazi koşullarında ölçümü zor ve zaman alıcı olan toprak kayıplarının dispersiyon analiz sonuçlarından yararlanarak tahmin edilebileceğini, uygulama ve işlemlerin toprak kayıplarının ulaşacağı boyuta etkisinin test edilmesine imkân verdiği, yüksek yağış yoğunluklarında parametrenin tahminleme etkisinin azaldığı ifade edilebilir.

\section{Sonuçlar}

Organik düzenleyici uygulamaları toprakların fiziksel ve kimyasal kalite parametreleri üzerinde pozitif etkiler göstermiştir. Toplam toprak-su kayıplarının fazla olarak belirlendiği uygulamalarda elde edilen kalite parametreleri daha 
düşük olarak gözlemlenirken, kayıpların daha az olduğu uygulamalarda ise bu parametre değerleri daha yüksek olarak belirlenmiştir. Bu çalışma ile toprakların belirlenen bazı fiziksel ve kimyasal kalite parametreleri arasında $\% 1$ ve $\% 5$ düzeyinde önemli pozitif ve negatif korelasyonlar elde edilmiştir.

Erozyon yoluyla topraklarda meydana gelen kayıplar üzerinde toprakların sahip oldukları fiziksel ve kimyasal özellikler, yağış özellikleri, eğim ve düzenleyici uygulamalarının etkili olduğu gözlemlenmiştir. Diğer taraftan erozyonu tahminlemede kullanılan parametrelerin de söz konusu faktörlerden etkilendiği tespit edilmiştir. AS parametresinin düşük ve yüksek yağış yoğunluklarında entisol ve inceptisol topraklarda erozyonla oluşan toprak kayıplarını tahminleme gücü sırasıyla $\left(r^{2}=0.78-072\right)$ ve $\left(r^{2}=0.92-0.81\right)$ olarak belirlenmiştir. Aynı sıralama ile dispersiyon oranının tahminleme gücü de $\left(\mathrm{r}^{2}=0.0 .57-048\right)$ ve $\left(r^{2}=0.47-0.46\right)$ şeklinde olmuştur. Fiziksel ve kimyasal özellikler içerisinde de özellikle tekstür ve organik maddenin diğer faktörlere kıyasla daha etkin olduğu sonucuna varılmıștır. Erozyonun sebep olduğu kayıpların önlenmesinde başvurulacak yöntemler ve uygulamalar seçilirken toprakların bu özellikleri dikkate alınarak uygulamalar belirlenmelidir.

Organik düzenleyiciler kullanılarak gerçekleştirilecek olan çalışmalarda uygulanacak doz miktarları yüksek tutulmalıdır. Ayrıca bu organik atıkların toprakta parçalanıp ayrışmasını sağlamak amaciyla gerçekleştirilen inkübasyon periyodu mümkün olduğunca uzun tutulmalıdır. Çünkü yeterli süre toprakta kalan ve organik madde düzeyini olumlu yönde etkileyecek olan organik materyaller toprağın agregasyon özelliklerini iyileştiren bir etken olacaktır.

\section{Kaynaklar}

Akça, E., Dinç, U., Serdem, M., Şenol, S., Eswaran, H., Kapur, S., 2007. Soils of Turkey: Status, problems and solutions. (Eds: P. Zdruli and G.T. Liuzzi), Mediterranean Conference, Status of Mediterranean Soil Resources: Actions Needed to Support Their Sustainable Use, Tunis, Tunisia, p: 315-339.

Albiach, R., Canet, R., Pomares, F., Ingelmo, F., 2001. Organic matter components, aggregate stability and biological activity in a horticultural soil fertilized with different rates of two sewage sludges during ten years. Bioresource Technology, 77(2): 109-114.

Anonymous, 1954. U.S. Salinity Laboratory Staff, Diagnosis and improvement of saline and alkali soils. Agriculture Handbook No: 60, USDA Water Conservation, 32: 130-132.

Bandyopadhyay, K.K., Misra, A.K., Ghosh, P.K., Hati, K.M., 2010. Effect of integrated use of farmyard manure and chemical fertilizers on soil physical properties and productivity of soybean. Soil and Tillage Research, 110(1): 115-125.

Bayrakl1, F., 1987. Toprak ve Bitki Analizleri. Ondokuz Mayıs Üniversitesi Yayınları, No: 17, Samsun.

Black, C.A., 1965. Methods of Soil Analysis Part I, American Society of Agronomy, No: 9, Inc. Madison.

Candemir, F., 1998. Çarşamba Ovası yüzey topraklarının bazı mekaniksel özellikleri ile strüktürel dayanıklılık ve erozyona duyarlılık ölçütlerinin belirlenmesi üzerine bir araștırma. Yüksek lisans tezi, Ondokuz Mayıs Üniversitesi Fen Bilimleri Enstitüsü, Samsun.

Clark, M.S., Horwath, W.R., Shennan C., Scow. K.M., 1998. Changes in soil chemical properties resulting from organic and low-input farming practices. Agronomy Journal, 90(5): 662-671.

Çimrin, K.M., Boysan, S., 2006. Van yöresi tarım topraklarının besin elementi durumları ve bunların bazı toprak özellikleri ile ilişkileri. Yüzüncü Yll Üniversitesi Ziraat Fakültesi Tarım Bilimleri Dergisi, 16(2), 105-111.

Demiralay, İ., 1993. Toprak Fiziksel Analizleri. Atatürk Üniversitesi Ziraat Fakültesi Yayınları No: 143, Erzurum.

Dinç, U., Kapur, S., Özbek, H., Şenol, S., 1999. Toprak Genesisi ve Sinıflandırılması. 3. Baskı, Çukurova Üniversitesi Ziraat Fakültesi Ders Kitabı, No: C-130, Adana.

Doran, J.W., Parkin, T.B., 1994. Defining and assessing soil quality. (Eds: J.W. Doran, D.C. Coleman, D.F. Bezdicek, and B.A. Stewart), Defining Soil Quality for a Sustainable Environment, Soil Science Society America Special Publication No: 35, Madison, 3-21.

Eriksen, G.N., Coale, F.J., Bollero, G.A., 1999. Soil nitrogen dynamics and maize production in municipal solid waste amended soil. Agrononmy Journal, 91(6): 1009-1016.

Erpul, G., Çanga, M.R., 2001. Toprak erozyon çalışmaları için bir yapay yağmurlama aletinin tasarım prensipleri ve yapay yağış karakteristikleri. Tartm Bilimleri Dergisi, 7(1): 75-83.

Faucette, L.B., Risse, L.M., Nearing, M.A., Gaskin, J.W., West, L.T., 2004. Runoff, erosion and nutrient losses from compost and mulch blankets under simulated rainfall. Journal of Soil and Water Conservation, 59(4): 154-160.

Graf, F., Frei, M., 2013. Soil aggregate stability related to soil density, root length, and mycorrhiza using sitespecific Alnus incana and Melanogaster variegatus s.l. Ecological Engineering, 57: 314-323.

Gregorich, E.G., Carter, M.R., Angers, D.A., Monreal, C.M., Ellert, B.H., 1994. Towards a minimum data set to assess soil organic matter quality in agricultural soils. Canadian Journal of Soil Science, 74(4): 367385.

Haynes, R.J., Naidu, R., 1998. Influence of lime, fertilizer and manure applications on soil organic matter content and soil physical conditions: a review. Nutrient Cycling in Agroecosystems, 51(2): 123-137. 
İç, S., Gülser, C., 2008. Tütün atığının farklı bünyeli toprakların bazı kimyasal ve fiziksel özelliklerine etkisi. Ondokuz Mayıs Üniversitesi Ziraat Fakültesi Dergisi, 23(2): 104-109.

Kacar, B., 1972. Bitki ve Toprağın Kimyasal Analizleri: II. Bitki Analizleri. Ankara Üniversitesi Ziraat Fakültesi Yayınları: 453, Uygulama Kılavuzu: 155, Ankara.

Kacar, B., 1994. Bitki ve Toprağın Kimyasal Analizleri: III. Toprak Analizleri. Ankara Üniversitesi Ziraat Fakültesi Eğitim Araştırma ve Geliştirme Vakfı Yayınları, No: 3, Ankara.

Kara, Z., 2012. Farklı orijinli organik atıklardan ayrışan bazı mineral maddelerin toprak profili boyunca taşınımı. Yüksek lisans tezi, Ondokuz Mayıs Üniversitesi Fen Bilimleri Enstitüsü, Samsun.

Karaca, A., 2004. Effect of organic wastes on the extractability of cadmium, copper, nickel, and zinc in soil. Geoderma, 122(2-4): 297-303.

Karaoğlu, M., Çanga, M.R., 2002. The consecutive simulated rainfall, slope and phosphogypsum's effects on runoff and erosion. International Conference on Sustainable Land Use Management, Sharing Experiences for Sustainable Use of Natural Sources, June 10-13, Çanakkale, Turkey, Proceeding Book, p: 282-289.

Lal, R., 1988. Soil Erosion Research Methods. Soil and Water Conservation Society Ankeny, Iowa.

Lal, R., Kimble, J.M., 1997. Conservation tillage for carbon sequestration. Nutrient Cycling in Agroecosystems, 49(1-3): 243-253.

Martinez, F., Casermeiro, M.A., Morales, D., Cuevas, G., Walter, I., 2003. Effects of run-off water quantity and quality of urban organic wastes applied in a degraded semi-arid ecosystem. The Science of the Total Environment, 305(1-3): 13-21.

Ngatunga, E.L.N., Lal, R., Uriyo, A.P., 1984. Effects of surface management on runoff and soil erosion from some plots at Mlingano, Tanzania. Geoderma, 33(1): $1-12$.

Özdemir, N., 1998. Toprak Fiziği. Ondokuz May1s Üniversitesi Ziraat Fakültesi Yayınları, No: 30, Samsun.
Özdemir, N., 2013. Toprak ve Su Koruma. Ondokuz Mayıs Üniversitesi Ziraat Fakültesi Yayınları No: 22, 3. Bask1, Samsun.

Richards, L.A., 1954. Diagnosis and Improvement of Saline and Alkali Soils. Agriculture Handbook No: 60, p. 105-106.

Rowell, D.L., 1996. Soil Science Methods and Applications. Wesley Longman Limited, Harlow, U.K.

Sağlam, M., 2013. Çok değişkenli istatistiksel yöntemler ile toprak özelliklerinin gruplandırılması. Toprak $S u$ Dergisi, 1: 7-14.

Sağlam, M.T., 1997. Toprak ve Suyun Kimyasal Analiz Yöntemleri. Trakya Üniversitesi Ziraat Fakültesi Yayın No: 189, Ders Kitab1 No: 5, 2. Bask1, Tekirdağ.

Sojka, R.E., Upchurch, D.R., 1999. Reservations regarding the soil quality concept. Soil Science Society of America Journal, 63(5): 1039-1054.

Sönmez, M., Y1lmaz, E., 2016. Biyo-gübre uygulamalarının agregat oluşumu üzerindeki rolü. Mediterranean Agricultural Sciences, 29(3): 131137.

Tejada, M., Gonzalez, J.L., 2003. Effects of the application of a compost originating from crushed cotton gin residues on wheat yield under dryland conditions. European Journal of Agronomy, 19(2): 357-368.

Tejada, M., Gonzalez, J.L., 2004. Effects of application of a byproduct of the two-step olive oil mill process on maize yield. Agronomy Journal, 96(3): 692-699.

Turgut, B., Aksakal, E.L., 2010. Fiğ samanı ve ahır gübresi uygulamalarının toprak aşınım parametreleri üzerine etkileri. Artvin Çoruh Üniversitesi Orman Fakültesi Dergisi, 11(1): 1-10.

Whalen, J.K., Chang, C., Clayton, G.W., Carefoot, J.P., 2000. Cattle manure amendments can increase the $\mathrm{pH}$ of acid soils. Soil Science Society of America Journal, 64(3): 962- 966.

Yakupoğlu, T., 2010. Samsun ili Minoz ve Gölet Havzalarında yaygınlık gösteren toprakların su erozyonuna duyarlılıklarının laboratuar koşullarında belirlenmesi. Doktora tezi, Ondokuz Mayıs Üniversitesi Fen Bilimleri Enstitüsü, Samsun. 